\title{
Th17 cells and HIV infection
}

\author{
Aimee ElHed ${ }^{1}$ and Derya Unutmaz ${ }^{1,2,3}$ \\ ${ }^{1}$ Department of Microbiology, New York University School of Medicine, New York, NY, 10016. \\ ${ }^{2}$ Department of Pathology, New York University School of Medicine, New York, NY, 10016.
}

\begin{abstract}
Purpose of review-This review summarizes the recent literature about the potential perturbation and role of Th17 cells in HIV pathogenesis. We discuss the recent findings on Th17 deficiency in HIV/SIV infection and how this may impact the mucosal host defenses, potentially contributing to chronic immune activation.
\end{abstract}

Recent findings-Th17 cells have been implicated in host defense against a variety of pathogens and are involved in the pathogenesis of autoimmune diseases. Recently Th17 cells were shown to be perturbed during HIV infection in humans and SIV infection in non-human primates. Th17 cells were found to be infected in vitro by HIV and SIV and are significantly depleted in the gastrointestinal (GI) tract of HIV-infected individuals. In monkeys, Th17 cells are only depleted in the pathogenic SIV infection of rhesus macaques, which correlates with the progression to AIDS in these primates, while they remain intact in the non-pathogenic SIV infection of African Green Monkeys or Sooty Mangabeys.

Summary-Th17 cells appear to be perturbed during HIV and SIV infection. This finding could have important implications in understanding the disruption of mucosal defenses in the GI tract and potentially in predicting opportunistic infections during the course of HIV disease.

\section{Keywords}

Th17; HIV; SIV; immune activation

\section{Introduction}

Th17 cells are a subset of effector T cells that promote inflammation through stimulating inflammatory cytokine release, chemokine expression and recruitment of neutrophils (1-6). Th17 cells mediate protective inflammatory reactions to a variety of bacterial and fungal pathogens (7-10) especially in the mucosal tissues and skin (11-14). However they are also implicated in causing pathogenic autoimmune diseases (15-20). Perturbation of Th17 cells during HIV infection at musocal sites, could therefore contribute to the pathogenesis of HIV either through increased susceptibility to bacterial and fungal infections or by disrupting the mucosal immune defenses. Here we review the recent findings on the role of Th17 cells during HIV and SIV infection and their potential contribution in HIV pathogenesis.

\footnotetext{
${ }^{3}$ Correspondence addressed to: 522 first ave. New York Univeristy School of Medicine, Smilow Research Building, Rm: 1011, New York, NY. Phone: 212-2639203 Derya@mac.com .

This is a PDF file of an unedited manuscript that has been accepted for publication. As a service to our customers we are providing this early version of the manuscript. The manuscript will undergo copyediting, typesetting, and review of the resulting proof before it is published in its final citable form. Please note that during the production process errors may be discovered which could affect the content, and all legal disclaimers that apply to the journal pertain.
} 


\section{Phenotype and Function of Th17 cells}

Th17 cells are defined by the secretion of IL-17, a proinflammatory cytokine mediating some of the effector functions of Th17 cells $(6,18,21-25)$, and by the expression of the transcription factor Retinoic Orphan Receptor $\gamma \mathrm{t}$ (ROR $\gamma \mathrm{t}$ ), which is required for their differentiation, both in mice and humans (26-28). In humans, all Th17 cells express CCR6, which directs homing of these cells to skin and mucosal tissues $(9,29,30),(31)$. Most Th17 cells are also thought to express IL-23R (32), which signals through IL-23, a proinflammatory cytokine that is required for the expansion and survival of these cells (33) (34). A portion of Th17 cells also express either Th2 associated chemokine receptor CCR4, or mutually exclusive Th1 associated CXCR3 (9). In addition, a sizeable portion of Th17 cells express HIV-coreceptor CCR5 $(35,36)$ and gut homing receptor $\alpha 4 \beta 7$ (37), which presumably allow them to migrate throughout mucosal tissues (38). Indeed, Th17 cells are enriched in the lamina propria of the GI tract and may play an important role in the defense against microbes at mucosal surfaces $(12,13,26)$.

Functionally, Th17 cells were shown to be involved in defense against extracellular bacteria such as Klebsiella pneumoniae (7), Mycobacterium Tuberculosis (39) and fungi such as Candida albicans in a murine model of systemic candidiasis (8). A role in host defense against Pneumocystis carinii was also suggested since as IL23p19-/- mice had impaired clearance of infection and did not contain any Th17 cells. In humans, it was recently reported that patients with hyper immunoglobulin E syndrome, characterized by recurrent staphylococcal and candida infections $(40,41)$ have impaired Th17 development $(42,43)$, further highlighting the role of Th17 responses in normal host defense against these pathogens.

Th17 cells are also implicated in variety of autoimmune inflammatory conditions. For example, the skin samples of psoriasis patients were found to contain high levels of IL-17A, IL-17F, and ROR $\gamma \mathrm{t}$ expression, and numerous IL-23 producing dendritic cells (DCs) were also present (32). Th17 cells have also been linked to several mouse models of inflammatory diseases, such as experimental autoimmune encephalomyelitis and collagen-induced arthritis $(17,44,45)$. An increased expression of IL-17 was also reported in multiple sclerosis patients (46) and in the inflamed mucosa or the serum of patients with inflammatory bowel disease (47).

While there is ample evidence implicating Th17 cells in both protective and harmful immune responses, their function in HIV infection is not yet fully characterized. Existence of HIV-specific Th17 cells were recently reported (48), suggesting a potential role for these cells in host defense against HIV. However, another study did not support this finding (49), thus it remains to be determined whether Th17 cells have direct anti-viral effector functions during HIV infection. Conversely, loss of Th17 cells in HIV infected individuals could have indirect consequences such as rendering them more prone to opportunistic bacterial and fungal infections (Figure 1). The concentration of Th17 cells at the mucosal tissues and their selective loss in these regions could also result in permeation of natural flora through mucosal linings, which in turn could result in unwanted immune activation, thus contributing to HIV pathogenesis (Figure 1).

\section{HIV and SIV infection of Th17 cells}

Recently it was found that the number of Th17 cells is reduced in the mucosa of HIVinfected individuals and SIV-infected macaques. In in vitro experiments it was found that sorted CD4+ Th17 cells from healthy macaques were infected by SIV $_{\text {mac251 }}$ by measuring p27 Gag in the supernatant of infected cultures (50). In adult blood from healthy individuals, we found that a sizeable portion of adult CD4+ Th17 cells express the HIV co-receptor 
CCR5 and produce very low levels of CCR5 ligands MIP- $1 \alpha$ and MIP-1 $\beta$ (36). Accordingly, CCR5+ Th17 cells were efficiently infected with CCR5-tropic HIV and were depleted during viral replication in vitro (36). While both SIV and HIV appears to infect Th17 cells in vitro, it remains to be determined whether this is the main reason for their disruption in vivo (Figure 1).

\section{Perturbation of Th17 cells in HIV-infected individuals}

Currently, little is known about whether Th17 cells are disrupted or expanded during HIV infection. A recent study comparing a group of HIV-1 infected children to uninfected pediatric subjects found a marked reduction in Th17 cells in PBMCs only from infected children with a plasma viral load higher than $50 \mathrm{copies} / \mathrm{ml}$ (51), showing a positive correlation between the reduction in Th17 cell number and plasma viral load. It is of interest to note that the frequency of IFN $\gamma$ cells was unchanged in these groups and that Th17 cells did not express CCR5. The authors of this study speculated that Th17 cells are not directly targeted by HIV but instead their differentiation is not sustained in vivo in HIV-1 positive children with a high viral load.

It is now well established that mucosal tissues are the major regions of HIV-replication, which results in drastic depletion of CD4+ effector T cells in the GI tract, possibly compromising mucosal defenses. Recent findings provide compelling evidence that the frequency of IL-17 producing CD4+ T cells is also significantly reduced in the GI tract of treatment naïve HIV-infected adults (49). Furthermore, only few of the remaining Th17 cells express CCR5, indicating a preferential loss of CCR5+ Th17 cells, and possibly arguing for a direct role of the virus-mediated depletion of this subset (49). Th17 cells are possibly important in host defense against extracellular bacteria in mucosal tissues through recruitment of neutrophils and production of antimicrobial peptides in the mucosa (12). The loss of Th17 cells in the gut of HIV-infected individuals might therefore compromise this mucosal line of defense, which normally limits bacterial dissemination from the intestinal mucosa (Figure 1). This is supported by the observation that IL-17 receptor-deficient mice developed increased systemic dissemination of Salmonella typhimurium from the gut to the mesenteric lymph nodes and spleen, which could explain the high occurrence of nontyphoidal Salmonella serotypes in HIV-infected individuals (52). Th17 responses, which dominate the gene expression profile from the ileal mucosa of S.typhimurium-infected rhesus macaques, were blunted when these macaques were also infected with SIV suggesting a Th17 deficiency during S.typhimurium infection in SIV-infected macaques compared to uninfected controls (52). How Th17 cells limit S.typhimurium dissemination from the intestinal mucosa is not yet known. Th17 depletion in the mucosa of HIV-infected individuals could also result in higher levels of lipopolysaccharide (LPS), derived from the bacteria translocated in the gut mucosa, in the blood of chronically HIV-infected individuals and SIV-infected rhesus macaques. The higher levels of LPS could in turn stimulate the innate immunity and result in systemic immune activation observed in pathogenic HIV and SIV infections (53).

An important question is whether Th17 cell loss during HIV infection cae restored. Macal et al. reported that the loss of Th17 cells appears to be reconstituted upon treatment (54). They showed that the highest level of CD4+ restoration during HAART correlated with a substantial increase in mucosal Th17 cells and a decreased level of inflammation as evidenced by gene profiling of inflammatory responses from jejunal biopsies. However, a low level of immune activation persisted in GALT despite long-term therapy. 


\section{Perturbation of Th17 cells in SIV-infected macaques}

African green monkeys (AGMs) and Sooty mangabeys (SMs) are natural SIV hosts that share many similarities with HIV infection of humans and SIV infection of Asian macaques; however they usually do not progress to AIDS $(55,56)$. During the acute phase of infection in both natural and non-natural SIV hosts, there is a peak in viral replication accompanied by high viral loads and depletion of mucosal CD4+ T cells (57). But during later stages, viral loads decline, which indicates a partial control of virus replication along with an active immune response. The difference, however, between natural and non-natural SIV hosts is in the chronic phase of infection where natural SIV hosts such as AGMs do not manifest a progressive depletion of mucosal or peripheral blood CD4+ T cells and the elevated immune activation they develop in the acute phase rapidly subsides $(55,56)$. Remarkably, despite not progressing to AIDS, these monkeys maintain relatively high viral load. The AGMs or SMs infected with SIV also do not manifest signs of microbial translocation from the intestinal lumen to the systemic circulation during chronic infection $(53,55,56)$. In contrast, SIVinfected macaques experience a rapid and drastic loss of mucosal CD4+ T cells during acute infection, which continues throughout the chronic phase along with depletion of circulating CD4+ T cells. The SIV-infected macaques also have immunostimulatory microbial products in their blood and display a generalized chronic immune activation $(53,55,56)$.

Recently, several papers determined the levels of Th17 cells in SIV infection. Brenchley et al compared SIV-infected SMs to uninfected controls and found that infected SMs maintained normal frequencies of Th17 cells in the GI tract, with a lower frequency of Th17 cells in the peripheral blood compared with uninfected SMs (49). However, the infection of macaques with pathogenic $\operatorname{SIV}_{\text {mac251 }}$ reduced the frequency of Th17 cells only at mucosal sites within a few weeks from infection (primary infection) and was not restored to normal levels in the chronic phase except in elite controller macaques (50). In healthy macaques, the frequency of Th17 cells is normally higher at the mucosal sites than the systemic tissues, whereas Th1 cells are equally distributed in all compartments. Th altered the balance of Th1 and Th17 cells during SIV infection, thus rendered Th1 to predominate over Th17 at the mucosal sites. SIV plasma viral load also negatively correlated with the percent of IL-17producing cells in this group of macaques (50).

In light of the difference in SIV pathogenesis between macaques and AGMs, a recent report compared SIV infection in pigtailed macaques (PTs) to that in AGMs (58). They found that infected PTs rapidly developed systemic immune activation with a high level of HLADR+ and Ki67+ cells in the blood, lymph node, colon and bone marrow; a marked and selective depletion of Th17 cells; and a loss of balance between Th17 and T regulatory (Treg) cells in the blood, mucosa, and lymphoid tissue. AGMs, on the other hand, maintained high and balanced levels of Th17 and Treg cells. A micro array analysis comparing PTs to AGMs at the time of infection and 45 days post infection found that the depletion of Th17 cells in PT macaques was selective because IFN $\gamma$ and IL-4 were maintained at the same levels in both species post infection (58).

It seems from the above studies that Th17 cells are an important contributor to SIV pathogenesis in macaques. Therefore, finding ways to maintain their frequencies at normal levels might slow down SIV disease progression.

\section{Role of Th17 cells in immune response against HIV infection}

Th17 depletion during HIV infection could also impact the natural immunity to HIV (Figure 1). A recent study did not find HIV-specific $\mathrm{T}$ cells that produce IL-17 in peripheral blood lymphocytes from HIV-infected individuals stimulated ex vivo with HIV antigens (49). However, another group reported the presence of HIV-specific Th17 cells in the blood of 
HIV-infected individuals during early infection that were undetectable during chronic or non progressive stages (defined as HIV-1 infected for less than 1 year, greater than 1 year, or greater than 10 years with no evidence of decline in the number of CD4+ T cells below 500/ $\mathrm{mm}^{3}$ respectively) (48). Therefore, it remains to be determined whether Th17 cells that recognize HIV antigens are present in HIV-infected individuals during different stages of the infection, and whether Th17 cell products, such as IL-17, promote or suppress HIV replication in target CD4+ T cells. Alternatively, Th17 cells could play a role in amplifying the innate responses to HIV infection, such as enhancing the expression of anti-microbial peptides $(59,60)$. It is also conceivable that Th17 cells have a detrimental role on the immune response to HIV infection. This possibility has become more plausible in light of a recent report that showed that Th17 cells could potentially enhance viral persistence and inhibit $\mathrm{T}$ cell cytotoxicity in murine encephalomyelitis virus infection model (61).

\section{Conclusion}

Recent studies suggest that Th17 cells are reduced in the gut of HIV-infected individuals, which could lead to bacterial translocation from the gut lumen to the systemic circulation and chronic immune activation. Depletion of Th17 cells in macaques but not in natural hosts like AGMs and SMs, could serve as an important contributing factor to the disease progression in SIV-infected macaques. While major gaps remain in our understanding of the role of Th17 cells during HIV infection, their potential perturbation during HIV/SIV infection could have important implications in understanding HIV disease progression.

\section{Acknowledgments}

We thank Frances Mercer, Stephen Rawlings, Angela Zou, and Alka Khaitan for critical reading and helpful suggestions on the review.

\section{References}

Papers of particular interest, published within the annual period of review, have been highlighted as:

- of special interest

•• of outstanding interest

1. Wynn TA. T(H)-17: a giant step from $\mathrm{T}(\mathrm{H}) 1$ and $\mathrm{T}(\mathrm{H}) 2$. Nat Immunol. Nov 6.2005 (11):1069-70. [PubMed: 16239919]

2. Bettelli E, Korn T, Kuchroo VK. Th17: the third member of the effector T cell trilogy. Curr Opin Immunol. Dec; 2007 19(6):652-7. [PubMed: 17766098]

3. Korn T, Oukka M, Kuchroo V, Bettelli E. Th17 cells: effector T cells with inflammatory properties. Semin Immunol. Dec; 2007 19(6):362-71. [PubMed: 18035554]

4. Stockinger B, Veldhoen M. Differentiation and function of Th17 T cells. Curr Opin Immunol. Jun; 2007 19(3):281-6. [PubMed: 17433650]

5. Stockinger B, Veldhoen M, Martin B. Th17 T cells: linking innate and adaptive immunity. Semin Immunol. Dec; 2007 19(6):353-61. [PubMed: 18023589]

6. Weaver CT, Hatton RD, Mangan PR, Harrington LE. IL-17 family cytokines and the expanding diversity of effector T cell lineages. Annu Rev Immunol. 2007; 25:821-52. [PubMed: 17201677]

7. Happel KI, Dubin PJ, Zheng M, Ghilardi N, Lockhart C, Quinton LJ, et al. Divergent roles of IL-23 and IL-12 in host defense against Klebsiella pneumoniae. J Exp Med. Sep 19; 2005 202(6):761-9. [PubMed: 16157683] 
8. Huang W, Na L, Fidel PL, Schwarzenberger P. Requirement of interleukin-17A for systemic antiCandida albicans host defense in mice. J Infect Dis. Aug 1; 2004 190(3):624-31. [PubMed: 15243941]

9. Acosta-Rodriguez EV, Rivino L, Geginat J, Jarrossay D, Gattorno M, Lanzavecchia A, et al. Surface phenotype and antigenic specificity of human interleukin 17-producing $\mathrm{T}$ helper memory cells. Nat Immunol. Jun; 2007 8(6):639-46. [PubMed: 17486092]

10. Rudner XL, Happel KI, Young EA, Shellito JE. Interleukin-23 (IL-23)-IL-17 cytokine axis in murine Pneumocystis carinii infection. Infect Immun. Jun; 2007 75(6):3055-61. [PubMed: 17403873]

11. Aujla SJ, Dubin PJ, Kolls JK. Interleukin-17 in pulmonary host defense. Exp Lung Res. Dec; 2007 33(10):507-18. [PubMed: 18075825]

12. Aujla SJ, Dubin PJ, Kolls JK. Th17 cells and mucosal host defense. Semin Immunol. Dec; 2007 19(6):377-82. [PubMed: 18054248]

13. Ivanov II, Frutos Rde L, Manel N, Yoshinaga K, Rifkin DB, Sartor RB, et al. Specific microbiota direct the differentiation of IL-17-producing T-helper cells in the mucosa of the small intestine. Cell Host Microbe. Oct 16; 2008 4(4):337-49. [PubMed: 18854238] •• First study to highlight the importance of the composition of the intestinal microbiota in Th17 cell differentiation. This observation has important implications in modulating the Th17:Treg balance in the gut which could influence the intestinal immunity and development of inflammatory bowel diseases.

14. Ivanov II, Atarashi K, Manel N, Brodie EL, Shima T, Karaoz U, et al. Induction of Intestinal Th17 Cells by Segmented Filamentous Bacteria. Cell. Oct 14.2009

15. Dardalhon V, Korn T, Kuchroo VK, Anderson AC. Role of Th1 and Th17 cells in organ-specific autoimmunity. J Autoimmun. Nov; 2008 31(3):252-6. [PubMed: 18502610]

16. Fouser LA, Wright JF, Dunussi-Joannopoulos K, Collins M. Th17 cytokines and their emerging roles in inflammation and autoimmunity. Immunol Rev. Dec.2008 226:87-102. [PubMed: 19161418]

17. Langrish CL, Chen Y, Blumenschein WM, Mattson J, Basham B, Sedgwick JD, et al. IL-23 drives a pathogenic $\mathrm{T}$ cell population that induces autoimmune inflammation. J Exp Med. Jan 17; 2005 201(2):233-40. [PubMed: 15657292]

18. Ogura H, Murakami M, Okuyama Y, Tsuruoka M, Kitabayashi C, Kanamoto M, et al. Interleukin-17 promotes autoimmunity by triggering a positive-feedback loop via interleukin-6 induction. Immunity. Oct 17; 2008 29(4):628-36. [PubMed: 18848474]

19. Oukka M. Th17 cells in immunity and autoimmunity. Ann Rheum Dis. Dec; 2008 67(Suppl 3):iii26-9. [PubMed: 19022809]

20. Sallusto F, Lanzavecchia A. Human Th17 cells in infection and autoimmunity. Microbes Infect. Apr; 2009 11(5):620-4. [PubMed: 19371794]

21. Kawaguchi M, Adachi M, Oda N, Kokubu F, Huang SK. IL-17 cytokine family. J Allergy Clin Immunol. Dec; 2004 114(6):1265-73. quiz 74. [PubMed: 15577820]

22. Kramer JM, Gaffen SL. Interleukin-17: a new paradigm in inflammation, autoimmunity, and therapy. J Periodontol. Jun; 2007 78(6):1083-93. [PubMed: 17539723]

23. Oda N, Canelos PB, Essayan DM, Plunkett BA, Myers AC, Huang SK. Interleukin-17F induces pulmonary neutrophilia and amplifies antigen-induced allergic response. Am J Respir Crit Care Med. Jan 1; 2005 171(1):12-8. [PubMed: 15477493]

24. Song C, Luo L, Lei Z, Li B, Liang Z, Liu G, et al. IL-17-producing alveolar macrophages mediate allergic lung inflammation related to asthma. J Immunol. Nov 1; 2008 181(9):6117-24. [PubMed: 18941201]

25. van Beelen AJ, Teunissen MB, Kapsenberg ML, de Jong EC. Interleukin-17 in inflammatory skin disorders. Curr Opin Allergy Clin Immunol. Oct; 2007 7(5):374-81. [PubMed: 17873575]

26. Ivanov II, McKenzie BS, Zhou L, Tadokoro CE, Lepelley A, Lafaille JJ, et al. The orphan nuclear receptor RORgammat directs the differentiation program of proinflammatory IL-17+ T helper cells. Cell. Sep 22; 2006 126(6):1121-33. [PubMed: 16990136]

27. Ivanov II, Zhou L, Littman DR. Transcriptional regulation of Th17 cell differentiation. Semin Immunol. Nov 27.2007 
28. Manel N, Unutmaz D, Littman DR. The differentiation of human $\mathrm{T}(\mathrm{H})-17$ cells requires transforming growth factor-beta and induction of the nuclear receptor RORgammat. Nat Immunol. Jun; 2008 9(6):641-9. [PubMed: 18454151] • This study shows that TGF $\beta$ is necessary for the differentiation of human Th17 cells from naïve precursors following the same requirements as the mouse counterpart, and highlighting the importance of this cytokine in the complex interplay between human Th17 and Treg cells.

29. Annunziato F, Cosmi L, Santarlasci V, Maggi L, Liotta F, Mazzinghi B, et al. Phenotypic and functional features of human Th17 cells. J Exp Med. Aug 6; 2007 204(8):1849-61. [PubMed: 17635957]

30. Singh SP, Zhang HH, Foley JF, Hedrick MN, Farber JM. Human T cells that are able to produce IL-17 express the chemokine receptor CCR6. J Immunol. Jan 1; 2008 180(1):214-21. [PubMed: 18097022]

31. Romagnani S. Human Th17 cells. Arthritis Res Ther. 2008; 10(2):206. [PubMed: 18466633]

32. Wilson NJ, Boniface K, Chan JR, McKenzie BS, Blumenschein WM, Mattson JD, et al. Development, cytokine profile and function of human interleukin 17-producing helper T cells. Nat Immunol. Sep; 2007 8(9):950-7. [PubMed: 17676044]

33. Oppmann B, Lesley R, Blom B, Timans JC, Xu Y, Hunte B, et al. Novel p19 protein engages IL-12p40 to form a cytokine, IL-23, with biological activities similar as well as distinct from IL-12. Immunity. Nov; 2000 13(5):715-25. [PubMed: 11114383]

34. Aggarwal S, Ghilardi N, Xie MH, de Sauvage FJ, Gurney AL. Interleukin-23 promotes a distinct CD4 T cell activation state characterized by the production of interleukin-17. J Biol Chem. Jan 17; 2003 278(3):1910-4. [PubMed: 12417590]

35. Lim HW, Lee J, Hillsamer P, Kim CH. Human Th17 cells share major trafficking receptors with both polarized effector T cells and FOXP3+ regulatory T cells. J Immunol. Jan 1; 2008 180(1): 122-9. [PubMed: 18097011]

36. ElHed A, Khaitan A, Kozhaya L, Manel N, Daskalakis D, Borkowsky W, et al. Human Th17 cells are susceptible to HIV and are perturbed during infection. J Infect Dis. in press.

37. Kleinschek MA, Boniface K, Sadekova S, Grein J, Murphy EE, Turner SP, et al. Circulating and gut-resident human Th17 cells express CD161 and promote intestinal inflammation. J Exp Med. Mar 16; 2009 206(3):525-34. [PubMed: 19273624] • This paper shows that CD161+ T cells associated with inflammatory diseases is the physiological pool of Th17 cells that can readily produce IL-17 when stimulated with IL-23 in inflammatory settings.

38. Berlin C, Berg EL, Briskin MJ, Andrew DP, Kilshaw PJ, Holzmann B, et al. Alpha 4 beta 7 integrin mediates lymphocyte binding to the mucosal vascular addressin MAdCAM-1. Cell. Jul 16; 1993 74(1):185-95. [PubMed: 7687523]

39. Cooper AM, Kipnis A, Turner J, Magram J, Ferrante J, Orme IM. Mice lacking bioactive IL-12 can generate protective, antigen-specific cellular responses to mycobacterial infection only if the IL-12 p40 subunit is present. J Immunol. Feb 1; 2002 168(3):1322-7. [PubMed: 11801672]

40. Minegishi Y, Saito M, Tsuchiya S, Tsuge I, Takada H, Hara T, et al. Dominant-negative mutations in the DNA-binding domain of STAT3 cause hyper-IgE syndrome. Nature. Aug 30; 2007 448(7157):1058-62. [PubMed: 17676033]

41. Holland SM, DeLeo FR, Elloumi HZ, Hsu AP, Uzel G, Brodsky N, et al. STAT3 mutations in the hyper-IgE syndrome. N Engl J Med. Oct 18; 2007 357(16):1608-19. [PubMed: 17881745]

42. Milner JD, Brenchley JM, Laurence A, Freeman AF, Hill BJ, Elias KM, et al. Impaired T(H)17 cell differentiation in subjects with autosomal dominant hyper-IgE syndrome. Nature. Apr 10; 2008 452(7188):773-6. [PubMed: 18337720] •• This study highlights the importance of STAT3 in the generation of human Th17 cells, and provides one possible mechanism that explains the recurrent infections seen in HIES patients.

43. de Beaucoudrey L, Puel A, Filipe-Santos O, Cobat A, Ghandil P, Chrabieh M, et al. Mutations in STAT3 and IL12RB1 impair the development of human IL-17-producing T cells. J Exp Med. Jul 7; 2008 205(7):1543-50. [PubMed: 18591412]

44. Cua DJ, Sherlock J, Chen Y, Murphy CA, Joyce B, Seymour B, et al. Interleukin-23 rather than interleukin-12 is the critical cytokine for autoimmune inflammation of the brain. Nature. Feb 13; 2003 421(6924):744-8. [PubMed: 12610626] 
45. Murphy CA, Langrish CL, Chen Y, Blumenschein W, McClanahan T, Kastelein RA, et al. Divergent pro- and antiinflammatory roles for IL-23 and IL-12 in joint autoimmune inflammation. J Exp Med. Dec 15; 2003 198(12):1951-7. [PubMed: 14662908]

46. Lock C, Hermans G, Pedotti R, Brendolan A, Schadt E, Garren H, et al. Gene-microarray analysis of multiple sclerosis lesions yields new targets validated in autoimmune encephalomyelitis. Nat Med. May; 2002 8(5):500-8. [PubMed: 11984595]

47. Fujino S, Andoh A, Bamba S, Ogawa A, Hata K, Araki Y, et al. Increased expression of interleukin 17 in inflammatory bowel disease. Gut. Jan; 2003 52(1):65-70. [PubMed: 12477762]

48. Yue FY, Merchant A, Kovacs CM, Loutfy M, Persad D, Ostrowski MA. Virus-specific interleukin-17-producing CD4+ T cells are detectable in early human immunodeficiency virus type 1 infection. J Virol. Jul; 2008 82(13):6767-71. [PubMed: 18434403] • This is the first study to demonstrate the presence of HIV-specific Th17 cells in HIV-infected individuals, which could imply Th17 cells in host defense against HIV infection.

49. Brenchley JM, Paiardini M, Knox KS, Asher AI, Cervasi B, Asher TE, et al. Differential Th17 CD4 T-cell depletion in pathogenic and nonpathogenic lentiviral infections. Blood. Oct 1; 2008 112(7):2826-35. [PubMed: 18664624] - This study shows that Th17 cells are depleted in the gut of HIV-infected individuals while they remain intact in the gut of SIV-infected sooty mangabeys. This observation could have important implications in explaining the mucosal dysfunction that accompanies HIV infection in humans.

50. Cecchinato V, Trindade CJ, Laurence A, Heraud JM, Brenchley JM, Ferrari MG, et al. Altered balance between Th17 and Th1 cells at mucosal sites predicts AIDS progression in simian immunodeficiency virus-infected macaques. Mucosal Immunol. Jul; 2008 1(4):279-88. [PubMed: 19079189] •• Th17 and not Th1 cells were shown to decline at mucosal sites in SIV-infected macaques, impairing the balance between these two subsets and possibly explaining the chronic enteropathy in HIV-individuals.

51. Ndhlovu LC, Chapman JM, Jha AR, Snyder-Cappione JE, Pagan M, Leal FE, et al. Suppression of HIV-1 plasma viral load below detection preserves IL-17 producing T cells in HIV-1 infection. Aids. May 11; 2008 22(8):990-2. [PubMed: 18453860]

52. Raffatellu M, Santos RL, Verhoeven DE, George MD, Wilson RP, Winter SE, et al. Simian immunodeficiency virus-induced mucosal interleukin-17 deficiency promotes Salmonella dissemination from the gut. Nat Med. Apr; 2008 14(4):421-8. [PubMed: 18376406] •• Th17 cells mediate the mucosal immune response to S. typhimurium infection in healthy rhesus macaques, and that their loss impairs the mucosal barrier, and results in systemic dissemination of S.typhimurium from the intestinal lumen to the circulation.

53. Brenchley JM, Price DA, Schacker TW, Asher TE, Silvestri G, Rao S, et al. Microbial translocation is a cause of systemic immune activation in chronic HIV infection. Nat Med. Dec; 2006 12(12):1365-71. [PubMed: 17115046]

54. Macal M, Sankaran S, Chun TW, Reay E, Flamm J, Prindiville TJ, et al. Effective CD4+ T-cell restoration in gut-associated lymphoid tissue of HIV-infected patients is associated with enhanced Th17 cells and polyfunctional HIV-specific T-cell responses. Mucosal Immunol. Nov; 2008 1(6): 475-88. [PubMed: 19079215] - This is the first study to demonstrate that gut CD4+ T cells can be restored in HIV-infected patients on HAART. This observation could have therapeutic implications especially that the CD4+ restoration was associated with a Th17 phenotype.

55. Paiardini M, Pandrea I, Apetrei C, Silvestri G. Lessons learned from the natural hosts of HIVrelated viruses. Annu Rev Med. 2009; 60:485-95. [PubMed: 19630581]

56. Sodora DL, Allan JS, Apetrei C, Brenchley JM, Douek DC, Else JG, et al. Toward an AIDS vaccine: lessons from natural simian immunodeficiency virus infections of African nonhuman primate hosts. Nat Med. Aug; 2009 15(8):861-5. [PubMed: 19661993]

57. Gordon SN, Klatt NR, Bosinger SE, Brenchley JM, Milush JM, Engram JC, et al. Severe depletion of mucosal CD4+ T cells in AIDS-free simian immunodeficiency virus-infected sooty mangabeys. J Immunol. Sep 1; 2007 179(5):3026-34. [PubMed: 17709517]

58. Favre D, Lederer S, Kanwar B, Ma ZM, Proll S, Kasakow Z, et al. Critical loss of the balance between Th17 and T regulatory cell populations in pathogenic SIV infection. PLoS Pathog. Feb. 2009 5(2):e1000295. [PubMed: 19214220] 
59. Liang SC, Tan XY, Luxenberg DP, Karim R, Dunussi-Joannopoulos K, Collins M, et al. Interleukin (IL)-22 and IL-17 are coexpressed by Th17 cells and cooperatively enhance expression of antimicrobial peptides. J Exp Med. Oct 2; 2006 203(10):2271-9. [PubMed: 16982811]

60. Peric M, Koglin S, Kim SM, Morizane S, Besch R, Prinz JC, et al. IL-17A enhances vitamin D3induced expression of cathelicidin antimicrobial peptide in human keratinocytes. J Immunol. Dec 15; 2008 181(12):8504-12. [PubMed: 19050268]

61. Hou W, Kang HS, Kim BS. Th17 cells enhance viral persistence and inhibit T cell cytotoxicity in a model of chronic virus infection. J Exp Med. Feb 16; 2009 206(2):313-28. [PubMed: 19204109] • A novel role for Th17 cells as a mediator of viral survival is described. This observation could have implications for the role of Th17 cells in immune response to HIV. 


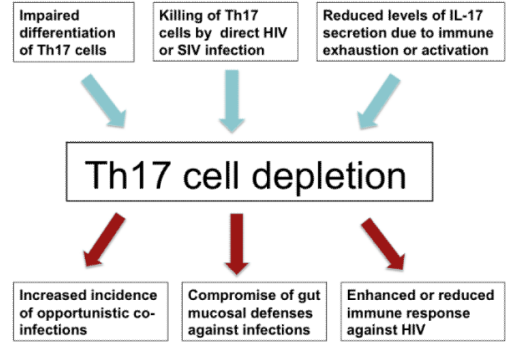

Figure 1.

Potential mechanisms and immunological consequences of Th17 depletion during HIV or SIV infection 